\title{
Effects of Sacharomyces cereviceae Incorporated Diet on Growth Performance, Apparent Digestibility Coefficient of Protein and Survival Rate of Catfish (Pangasius hypothalamus)
}

\author{
Diana Rachmawati*, Istiyanto Samidjan, Ristiawan Agung Nugroho, Titik Susilowati \\ Aquaculture Study Program, Diponegoro University, Semarang, Indonesia \\ *Corresponding Email : dianarachmawati1964@gmail.com
}

\begin{abstract}
Diana Rachmawati, Istiyanto Samidjan, Ristiawan Agung Nugroho, Titik Susilowati. 2019. Effects of Sacharomyces cereviceae Incorporated Diet on Growth Performance, Apparent Digestibility Coefficient of Protein and Survival Rate of Catfish (Pangasius hypothalamus). Aquacultura Indonesiana, 20 (1): 8-14. A new culture system is introduced to maximize diet usage for growth of Catfish (Pangasius hypothalamus). The new culture system is by incorporating Saccharomyces cerevisiae into the feed. It aims to increase feed efficiency; in turn it increases the growth of fish. The objective of the research is to know the effects of $S$. cereviceae incorporated diet on growth performance, apparent digestibility coefficient of protein and survival rate of catfish (P. hypothalamus). The average wight of fish used in the study were $4.02 \pm 0.22 \mathrm{~g}$. The study used experimental method with completely random design, with 4 (four) treatments and each treatment had 4 (four) replications. The treatments were 4 different dosages of $S$. cerevisiae addition in the diet, i.e; $0 \mathrm{~g} \mathrm{per} \mathrm{kg}$ feed (A), $0.5 \mathrm{~g}$ per $\mathrm{kg}$ feed (B), $1 \mathrm{~g}$ per $\mathrm{kg}$ feed (C) and $2 \mathrm{~g}$ per $\mathrm{kg}$ feed (D). The results show that the incorporated of $S$. cerevisiae in feed has significant effect $(\mathrm{P}<0.05)$ on the specific growth rate $(\mathrm{SGR})$, apparent digestibility coefficient of protein $\left(\mathrm{ADC}_{\mathrm{P}}\right)$ and survival rate $(\mathrm{SR})$ of the catfish ( $P$. hypothalamus) fingerlings. The optimum dosages of $S$. cerevisiae for $\mathrm{SGR}, \mathrm{ADC}_{\mathrm{P}}$ and $\mathrm{SR}$ of the Catfish ( $P$. hypothalamus) fingerlings ranged from 1 to $1.08 \mathrm{~g} / \mathrm{kg}$ feed.
\end{abstract}

Keywords : Catfish ; Saccharomyces cerevisiae ; Protein digestibility ; Growth performance;

\section{Introduction}

Feeding is the main factor in the success of Catfish (Pangasius hypothalamus) aquaculture. As reported by MuhammadLawal and Omotesho (2010) that feed is one of the important factors in aquaculture and $50 \%$ of the cost is for feed (Rana et al,. 2009). Costly of feed is often due to an inefficiency of feed. The fish cannot efficiently utilize the feed to grow. Incorporation of feed additive such as enzyme, probiotic, prebiotic or immunostimulant into the feed for fish could be considered as an alternative to solve that problem. Yeast ( Saccharomyces cerevisiae) has been used as an immunostimulant to increase fish immune system (Tewary and Patra, 2011). Sakai et al. (2001) reported that the suplementation of immunostimulant in the diet significantly boost growth and immunity in fish and crustacean. Yeast contains high nutrients such as protein, fat, vitamin, and minerals (Abu-Elala et al., 2013). The supplementation of the Saccharomyces cerevisiae in the feed could increase digestibility of feed and protein, therefore it raised feed efficiency, growth, and immunity of the fish (Wache et al., 2006; Abdel-Tawwab et al., 2008; Abu-Elala et al., 2013). The digestibility increase was due to the ability of Saccharomyces cerevisiae to increase digestive enzyme in the fish disgeting system. The findings of the study had similar findings with the some studies conducted by Tewary et al. (2011) in Labeo rohita, He et al. (2009) and Abu-Elala et al. (2013) in Oreochromis niloticus, Semih et al. (2009) in gilthead sea bream, and Pooramini et al. (2009) in rainbow trout fry .

The use of $S$. cerevisiae has some advantages, such as fast, easy, and cheap to pro duce. It can also be recycled from other industry waste and a natural substance without negative effect whether for the animal or the 
environment (Tewary and Patra, 2011). Olvera et al. (2001) also reported that yeast ( $S$. cerevisiae) has a positive effect on the growth and the feed efficiency, as also reported by Pangrahi et al. (2005), Barnes et al. (2006) and Abo-State et al. (2009). Moreover, Korkmaz and Cakirogullari (2011) and $\mathrm{He}$ et al. (2009) suggested that the addition of $S$. cerevisiae in the feed could increase the growth of tilapia and carper.

Information on the study of addition of $S$. cerevisiae in the feed in catfish ( $P$. hypopthalmus) is very limited; therefore, the study is very important especially to find out the effects of addition of $S$. cerevisiae in the feed on the efficiency of feed and growth of catfish. The objective of the research is to find out the effects of $S$. cereviceae incorporated diet on growth performance, apparent digestibility coefficient of protein and survival rate of catfish ( $P$. hypothalamus).

\section{Materials and Methods}

\section{Experimental System}

The experiments were conducted in 16 aquariums in the Center for Hatchery and Freshwater Aquaculture, Muntilan, Central Java, Indonesia. The study took place from August to December 2017. Each aquarium was filled with 251 of water and stocked with 50 catfish fingerlings. The average weight of the fingerling was $4.02 \pm 0.22 \mathrm{~g}$. The total stock was 800 fingerlings that were obtained from the center. Before the fingerlings were stocked in the aquarium, the fingerlings were first acclimated in the special container for 2 (two) weeks with the temperature of $31-33{ }^{\circ} \mathrm{C}$ and water $\mathrm{pH}$ of $7,42-7,53$. To maintain dissolved oxygen at $6 \mathrm{mg} / \mathrm{l}$, aerators were installed in each aquarium during the study. After acclimation, healthy and similar size of fingerlings were selected (Rachmawati et al., 2017), then they were weighed and stocked into the aquariums according to the experimental setting.

\section{Experimental Design}

The study used Completely Random Design ex periment. The experiment has 4 (four) treatments and each treatment has 4 (four) repetition. The treatment in the study was implementing various dosages of Saccharomyces cerevisiae incorporated diets.

\section{Container Preparation}

Containers used in the study were aquariums. Each aquarium has the dimension of $50 \times 30 \times 30 \mathrm{~cm}^{3}$. Each aquarium was installed with aerator. Containers, tools, and media were sterilized with disinfectant. The disinfectant was $5 \mathrm{mg} / \mathrm{L}$ chlorine $\left(\mathrm{Cl}_{2}\right)$ and kept in one day. After that, they were neutralized with $3 \mathrm{mg} / \mathrm{L}$ natrium triosulphat $(\mathrm{Na} 2 \mathrm{SO} 3)$ and rinsed with water (APHA, 1992). Then the aquariums were filled with fresh water as needed.

\section{Preparing Diet and Treatment Procedure}

The study used diet containing 32\% protein which was obtained from commercial market. The treatments were by adding Saccharomyces cerevisiae into the feed with dosages of $0 \mathrm{~g}$ per $\mathrm{kg}$ feed (A), $0.5 \mathrm{~g}$ per $\mathrm{kg}$ feed (B), $1 \mathrm{~g}$ per $\mathrm{kg}$ feed (C) and $2 \mathrm{~g}$ per $\mathrm{kg}$ feed (D).To produce the experimental feed, first the feed wascrushed, sieved and then mixed with yeast Saccharomyces cerevisiae and oil. Then the mixture was added water and blended to get firm dough. The firm dough was formed into pellets. The pellets were stored at the temperature of $-20^{\circ} \mathrm{C}$ until it was used for the experiment.

Fish fed experimental feed in satiation level twice everyday, in the morning and in the afternoon for 49 days. Uneaten feed was taken out using pipet 30 minutes after feeding. The collecting feed waste was dried at $75{ }^{\circ} \mathrm{C}$. Then the dried uneaten feed was weighed.

To get the weight data of the fish, each fish was weighed everyweek. To maintain good water quality in aquarium, $25 \%$ of water was replaced everyday.

\section{Chemical Analysis of Diet}

Diet for every treatment was analyzed for protein, fat and ash content based on AOAC (2006) method. Ash was obtained by 
baking the feed in the furnace for 6 hoursat $550^{\circ} \mathrm{C}$ (Thermolyne Corporation, Dubuque, IO, USA).

\section{Water Quality Analysis}

Water quality $(\mathrm{pH}, \mathrm{DO}$, Alkalinity, Ammonia) from the aquarium was measured every week using APHA method (1992) and maintained at the normal level.

\section{Fish Performance}

Parameters observed for fish performance were Specific Growth Rate (SGR) and Survival Rate (SR) based on Tacon (1992), while Apperent Digestibility of Protein $\left(\mathrm{ADC}_{\mathrm{P}}\right)$ was based on Fennuci (1981). Efficiency of Feed Utilization (EFU), Food Conversion Ratio (FCR), and Protein Efficiency Ratio (PER) were based on Takeuchi (1988). The calculation of the parameters values were as follows:

-) $\mathrm{ADC}_{\mathrm{P}}=100\left(\% \mathrm{Cr}_{2} \mathrm{O}_{3}\right.$ in the feed $/ \% \mathrm{Cr}_{2} \mathrm{O}_{3}$ in the feces $) \times(\%$ protein in the feces/\%protein in the feed);

-) $\mathrm{EFU}(\%)=100$ (final weight-initial weight)/the amount of feed consumed;

-) SGR $(\%)=100(\ln \mathrm{W} 2-\ln \mathrm{W} 1) / \mathrm{T}$; where
$\mathrm{W} 1$ and $\mathrm{W} 2$ are the initial and final weight of fish, respectively, and $\mathrm{T}$ is the number of days in the feeding period

-) $\mathrm{FCR}=($ feed intake $(\mathrm{g}) /$ weight gain $(\mathrm{g})$;

-) PER = (weight gain $(\mathrm{g}) /$ protein intake $(\mathrm{g})$ );

-) $\mathrm{SR}(\%)=100$ (final number of fish/initial number of fish)

\section{Statistical Analyses}

Statistical analysis of parameter data was observed using Anova test, Duncan test and othogonal polynomial (Steel et al., 1996). While water quality data was analyzed descriptively.

\section{Results}

The results of SGR, $\mathrm{ADC}_{\mathrm{P}}, \mathrm{EFU}, \mathrm{FCR}$, PER and SR of Catfish ( $P$. hypothalamus) fingerlings were shown in Table 1.

The relationships of biological response variables and the regression equation of Catfish (P. hypopthalmus) to the experimental feed containing various dietary $S$. cerevisiae based on the polynomial orthogonal test were depicted in Table 2.

The water quality parameters during the study were presented in Table 3

Table 1. The Values ofADCP, SGR, EFU, FCR PER, and SR of fish fed experimental feed for 49 days

\begin{tabular}{lrrrr}
\hline \multirow{2}{*}{ Parameters } & \multicolumn{4}{c}{ Treatments } \\
\cline { 2 - 5 } & \multicolumn{1}{c}{$\mathrm{A}$} & $\mathrm{B}$ & $\mathrm{C}$ & \multicolumn{1}{c}{$\mathrm{D}$} \\
\hline $\mathrm{ADC}_{\mathrm{P}}(\%)$ & $50.43 \pm 0.03^{\mathrm{d}}$ & $65.24 \pm 0.05^{\mathrm{c}}$ & $75.56 \pm 0.04^{\mathrm{a}}$ & $70.34 \pm 0.04^{\mathrm{b}}$ \\
\hline SGR $(\% /$ day $)$ & $1.78 \pm 0.02^{\mathrm{c}}$ & $2.45 \pm 0.03^{\mathrm{b}}$ & $3.56 \pm 0.02^{\mathrm{a}}$ & $2.21 \pm 0.02^{\mathrm{b}}$ \\
\hline EFU $(\%)$ & $60.68 \pm 0.06^{\mathrm{d}}$ & $75.85 \pm 0.06^{\mathrm{c}}$ & $83.73 \pm 0.09^{\mathrm{a}}$ & $70.42 \pm 0.07^{\mathrm{b}}$ \\
\hline FCR & $2.50 \pm 0.03^{\mathrm{c}}$ & $2.03 \pm 0.05^{\mathrm{b}}$ & $1.54 \pm 0.05^{\mathrm{a}}$ & $2.02 \pm 0.04^{\mathrm{b}}$ \\
\hline PER & $1.72 \pm 0.02^{\mathrm{c}}$ & $2.06 \pm 0.03^{\mathrm{b}}$ & $2.64 \pm 0.01^{\mathrm{a}}$ & $2.00 \pm 0.03^{\mathrm{b}}$ \\
\hline SR $(\%)$ & $75.33 \pm 0.09^{\mathrm{c}}$ & $85.33 \pm 0.35^{\mathrm{b}}$ & $90.33 \pm 0.89^{\mathrm{a}}$ & $80.33 \pm 0.14^{\mathrm{b}}$ \\
\hline
\end{tabular}

Table 2. The Regression Equation of Catfish (P. hypopthalmus) on the Experimental Feed Containing Various Dosages of Dietary S. Cerevisiae

\begin{tabular}{|c|c|c|c|}
\hline $\begin{array}{c}\text { Response } \\
\text { variable }(\mathrm{Y})\end{array}$ & Regression equation & $\begin{array}{c}\text { Optimum level } \\
\text { Dose of } S \text {. Cerevisiae } \\
\text { (g/kg diet) }\end{array}$ & $\begin{array}{l}\text { Maximum } \\
\text { value of Y }\end{array}$ \\
\hline SGR (\%/day) & $Y=-0.79 x^{2}+1.665 x+1.605, R^{2}=0.88$ & 1 & 3.56 \\
\hline EFU (\%) & $Y=-22.944 x^{2}+50.852 x+55.538, R^{2}=0.99$ & 1.11 & 85.03 \\
\hline FCR & $Y=0.5355 x^{2}-1.1697 x+2.1757, R^{2}=0.99$ & 1 & 1.54 \\
\hline $\mathrm{ADC}_{\mathrm{P}}(\%)$ & $Y=-15.523 x^{2}+35.743 x+55.741, R^{2}=0.99$ & 1 & 75.56 \\
\hline PER & $Y=-0.5745 x^{2}+1.2833 x+1.5987, R^{2}=0.98$ & 1.12 & 2.71 \\
\hline SR $(\%)$ & $Y=-0.5633 x^{2}+1.2633 x+1.4987, R^{2}=0.98$ & 1.08 & 92.31 \\
\hline
\end{tabular}


Table 3. Values of water quality parameters during the study

\begin{tabular}{|l|r|r|r|r|}
\hline \multirow{2}{*}{ Treatment } & \multicolumn{4}{|c|}{ Water Quality Parameters } \\
\cline { 2 - 5 } & Temperature $\left({ }^{0} \mathrm{C}\right)$ & $\mathrm{pH}$ & \multicolumn{1}{c|}{ DO $(\mathrm{mg} / \mathrm{l})$} & \multicolumn{1}{c|}{$\mathrm{NH}_{3}(\%)$} \\
\hline $\mathrm{A}$ & $26-31$ & $7.23-7.65$ & $4.08-5.13$ & $0.004-0.005$ \\
\hline $\mathrm{B}$ & $26-31$ & $7.10-7.72$ & $3.84-5.12$ & $0.004-0.005$ \\
\hline $\mathrm{C}$ & $26-31$ & $7.42-7.61$ & $4.23-5.21$ & $0.004-0.005$ \\
\hline D & $26-31$ & $7.33-7.62$ & $4.12-5.23$ & $0.004-0.005$ \\
\hline Feasibility & $14-38^{*}$ & $6.50-8.5^{*}$ & $>2^{*}$ & $<0.1^{*}$ \\
\hline
\end{tabular}

Note : * Boyd (2003)

\section{Discussion}

The resuts of anova show that the $S$. cerevisiae supplementation into the feed has a significant effect on the catfish SGR. The catfish fingerlings fed with $S$. cerevisiae addition of $0.5-2.0 \mathrm{~g} / \mathrm{kg}$ feed has the value of SGR as much as $2.21-3.56 \% /$ day. It was higher than that of the value of SGR without the addition of $S$. cerevisiae in the feed, i.e., $1.78 \% /$ day. The highest value of SGR (3.56\%/day) was obtained when the fingerlings were fed with the dosage of $1.0 \mathrm{~g} S$. cerevisiae/kg feed (treatment C). It was followed by treatment $\mathrm{B}, \mathrm{D}$, and $\mathrm{A}$ with the values of $2.45 \% /$ day, $2.21 \% /$ day and $1.78 \% /$ day. The value of SGR in the treatment C was thought that the dosage of $S$. cerevisiae $(1.0 \mathrm{~g} / \mathrm{kg}$ feed) was an appropriate dosage to increase protein digestibility and efficiency of feed utilization; therefore it boosts growth of catfish fingerlings. The digestibility increase was due to the ability of Saccharomyces cerevisiae to increase digestive enzyme in the fish disgeting system fish disgeting system. Gawlicka et al. (2000) and German et al. (2004) suggested that S. cerevisiae incorporated diet could increase growth due to increasing of alkali phosphate activities. The result were also in line with the findings in Labeo rohita (Tewary et al., 2011), Cyprinus carpio (Manopo and Kolopita, 2016), Oreochromis niloticus (He et al, 2009; AbuElala et al., 2013), gilthead sea bream (Semih et al., 2009), rainbow trout fry's (Pooramini et $a l, 2009)$. The result of polynomial orthogonal test about the relationship between $S$. crevisiae supplementation and SGR value was shown in the Table 2. The optimum dosage of $S$. crevisiae supplementation can be drawn from the equation. The optimum dosage of $S$. crevisiae was $1 \mathrm{~g} / \mathrm{kg}$ feed and resulted in the SGR of $3.56 \% /$ day.

The results of ANOVA also show that $\mathrm{S}$. cerevisiae incorporated diet has significant effect on EFU and FCR of catfish fingerlings, as shown in the Table 1 . The feeding of the $S$. cerevisiae addition of $0.5-2.0 \mathrm{~g} / \mathrm{kg}$ feed resulted higher value of EFU (70.42-83.73\%) compared to the feeding without the addition of $S$. cerevisiaein the feed $(60.68 \%)$. Moreover, the addition of $S$. cerevisiae in the feed (0.5$2.0 \mathrm{~g} / \mathrm{kg}$ feed) brought about FCR to decrease become $1.54-2.03$ compared to without the addition of $S$. cerevisiae in the feed which has FCR as mch as 2.50 . The study showed that $S$. crevisiae supplementation in the feed could increase EFU and resulted lower FCR.

The highest value of EFU was obtained when the fingerlings were fed with the. dosage of $1.0 \mathrm{~g} \mathrm{~S}$. cerevisiae per $\mathrm{kg}$ feed $(83.73 \%)$, followed by treatments B $(74.85 \%)$, D $(65.42$ $\%)$ and $\mathrm{A}(55.68 \%)$. The result of polynomial orthogonal test about the relationship between $S$. cerevisiae supplementation and EFU value was shown in the Table 2. The optimum dosage of $S$. cerevisiae supplement was calculated using the equation of EFU on $S$. cerevisiae supplementation. The optimum dosage was $1.11 \mathrm{~g} / \mathrm{kg}$ feed and resulted in the EFU of $85.03 \%$. While the lowest values of FCR was obtained from the treatment $\mathrm{C}$ (1.0 $\mathrm{g} / \mathrm{kg}$ feed) with the lowest value of 1.54. That value was followed by the treatment B (2.03), $\mathrm{D}$ (2.02) and A (2.50). The relationship between $S$. cerevisiae supplementation and FCR was drawn as shown in the Table 2. From the equation, the optimum dosage of $S$. cerevisiae supplementation was obtained with 
the optimum value of 1.54 . The addition of $S$. cerevisiae in the feed increased efficiency of feed utilization and decreased FCR of fish due to the Tawwab et al. (2008) also found the similar result for tilapia.

The improvement of growth and efficiency of feed utilization in the present study was because of the increase of protein digestibility. Table 1 show that $\mathrm{ADC}_{\mathrm{P}}$ increased due to the availability of $S$. cerevisiae incorporated diet. The fingerlings fed with the addition of $0.5-2.0 \mathrm{~g} S$. cerevisiae per $\mathrm{kg}$ feed has higher value of $\mathrm{ADC}_{\mathrm{P}}$ compared to the value of $\mathrm{ADC}_{\mathrm{P}}$ without the addition of $S$. cerevisiae in the feed. In this case, $S$. cerevisiae as an imunostimulant can increase enzyme production in the digestive system, in turn it improved protein digestibility (Welker and Lim, 2011). Meanwhile, Merrifield et al. (2010), Nayak (2010) and Welker and Lim (2011) suggested that imunostimulant improved digestibility and the absorption of nutrients, amino acid, vitamins and enzymes. The result of polynomial orthogonal test about the relationship between $S$. cerevisiae supplementation and ADCp value was shown in the Table 2. The optimum dosage of $S$. crevisiae was $1 \mathrm{~g} / \mathrm{kg}$ feed and resulted in ADCp of $75.56 \%$.

The addition of $S$. cerevisiae in the feed can significantly increased efficiency of feed utilizationas, PER and SR. The catfish fingerlings fed with the addition of $1.0 \mathrm{~g} S$. cerevisiae per $\mathrm{kg}$ feed (treatment $\mathrm{C}$ ) had highest values of EFU, PER, SR, and the lowest value of FCR, as shown in the Table 1. The highest values of PER and SR of the catfish were obtained from the treatment $\mathrm{C}$ (1 g.kg feed) with the values of 2.64 and $90.33 \%$ respectively. Those values were followed by the treatment B $(2.06 ; 85.33 \%), \quad \mathrm{D}$ $(2.00 ; 80.33 \%)$ and A $(1.72 ; 75.33 \%)$. Tovar et al. (2002) and Wache et al. (2006) also suggested that the $S$. cerevisiae supplementation in the feed was significantly able to increase protein digestibility; therefore, it can maximize the efficiency of feed utilization, increased protein efficiency ratio and survival rate, while it decreased feed conversion ratio. Abdel-Tawwab et al. (2008) also found the similar result in the case of tilapia, while Tovar et al. (2002) and Wache et al. (2006) found in sea bass and rainbow trout, increase of protein digestibility (Tovar et al. (2002); Wache et al (2006). Abdel-

respectively. The result of polynomial orthogonal test about the relationship between $S$. cerevisiae supplementation and PER value was shown in the Table 2. The optimum dosage of $S$. cerevisiae supplementation in the feed for PER derived from the equation was $1.12 \mathrm{~g} / \mathrm{kg}$ feed with the PER value of 2.71 . The relationship between $S$. cerevisiae supplementation and SR value was also shown in the Table 2. The optimum dosage of $S$. cerevisiae supplementation in the feed for SR derived from the equation was $1.08 \mathrm{~g} / \mathrm{kg}$ feed with the SR value of $92.31 \%$.

Table 3 indicating that water quality during the study was still in a reasonable range for catfish P. hypopthalmus cultivation.

\section{Conclusion}

The supplementation of $S$. cerevisiae in the feed could increase SGR, $\mathrm{ADC}_{\mathrm{P}}$, and SR of catfish ( $P$. hypothalamus) fingerlings. The optimum dosage of $S$. cerevisiae for good $\mathrm{SGR}, \mathrm{ADC}_{\mathrm{P}}$, and $\mathrm{SR}$ of catfish fingerlings were 1,1 and $1.08 \mathrm{~g} / / \mathrm{kg}$ of feed, respectivel

\section{Acknowledgment}

The authors thank the Center for Hatchery and Freshwater Aquaculture, Muntilan, Central Java, Indonesia for providing infrastructure facilities. The authors also thank the Department of Aquaculture of Fisheries, the Faculty of Fisheries and Marine Sciences, Diponegoro University for all valuable work facilities to prepare this article.

\section{References}

Abdel-Tawwab, M., Khattab, Y.A.E., Ahmad,
M.H., Shalaby, A.M.E. 2008.
Compensatory growth, feed utilization,
whole-body composition and
hematological changes in starved juvenile
Nile tilapia, Oreochromis niloticus (L.). J.
Appl. Aquac, 18:17-36.
Abo-State, H.A. El-Kholy, Kh.F. and Al-Azab, A.A. 2009. Evaluation of probiotic 
(EMMH) as a growth promoter for Nile tilapia (Oreochromis niloticus) fingerlings. Egyptian Journal of Nutrition and Feeds, 12(2): 347-358.

Abu-Elala, N., Marzouk, M., Moustafa, M. 2013.Use of different Saccharomyces cerevisiae biotic forms as immunemodulator and growth promoter for Oreochromis niloticus challenged with some fish pathogens. International Journal of Veterinary Science and Medicine, 1: 2129

AOAC (Association of Official Analytical Chemists). 2006. Official Methods of Analysis, Association of Official Analytical Chemists International, Arlington, Va, USA, $18^{\text {th }}$ edition.

APHA. 1992. Standard Methods for the Examination of Water and Wastewater. American Public Health Association Washington.D.C.185P.

Barnes, M.E., Durben, D.J., Reeves, S.G. and Sanders, R., 2006. Dietary yeast culture supplementation improves initial rearing of strain rainbow trout. Aquaculture Nutrition, 12(5): 388-394.

Boyd, C.E. 2003. Guidelines for aquaculture effluent management at the farm level. Aquaculture 226:101-112.

Fennuci, J.L. 1981. Studies on the nutrition of marine shrimp of the Penaeus. Ph.D. Thesis, Faculty of Department of Biology, University of Houston, Houston, Texas, USA.

Gawlicka, A., Parent, B., Horn, M.H., Ross, N. and Opstad, I., 2000. Activity of digestive enzymes in yolksac larvae of Atlantic halibut (Hippoglossus hippoglossus): Indication of readiness for first feeding. Aquaculture, 184: 303-314.

German, D.P., Horn, M.H. and Gawlicka, A., 2004. Digestive enzyme activities in herbivorous and carnivorous prickle back fishes (Teleostei: Stichaeidae): Ontogenetic, Dietary, and Phylogenetic Effects. Physiological and Biochemical Zoology, 77: 789-804.

He, S., Zhigang Z., Yuchun, L., Shi, P., Bin, Y., Einar, R., Ilkyu,Y. 2009. Effects of dietary Saccharomyces cerevisiae fermentation product (DVAQUA) on growth performance, intestinal autochthonous bacterial community and non-specific immunity of hybrid tilapia ( $O$. niloticus $x O$. aureus) cultured in cages. Aquaculture, 294: 99-107.

Korkmaz, A.S. and Cakirogullari, G.C. 2011. Effects of partial replacement of fish meal by dried baker's yeast (Saccharomyces cerevisiae) on growth performance, feed utilization and digestibility in Koi carp (Cyprinus carpio L., 1758) fingerlings. Journal of Animal and Veterinary Advances, 10(3): 346-35.

Manoppo, H., and Kolopita, M.E.F. 2016. The use of baker's yeast to promote growth of carp (Cyprinus carpio L). International Journal of PharmTech Research, 9 (9) : 415-420.

Merrifield, D.L., Dimitroglou, A., Foey, A., Davies, S.J. and Baker, R.T.M. 2010. The current status and future focus of probiotic and prebiotic applications for salmonids. Aquaculture, 302: 1-18.

Muhammad-Lawal, A., and Omotesho, O. A. 2010. Economic analysis of fish farming in the North Central Nigeria: a case study of Kwara and Kogi states. Journal of Agricultural Research and Development, 9 (1): 21-36.

Nayak, S.K., 2010. Role of gastrointestinal microbiota in fish. Aquaculture Research, 41: 1553-1573.

Olvera, M.A., Lara, M., Guzman, B.E. and Lopez, W.G. 2001. Effect of the use of probiotics on growth of tilapia Oreochromis niloticus reared under stress conditions. World Aquaculture Society, 497: Aquaculture-Book of abstracts 143.

Pangrahi, A., Kiron, V., Puangkaew, J., Kobayashi, T., Satoh, S., and Sugita, H. 2005. The viability of probiotic bacteria as a factor influencing the immune response in Rainbow trout Oncorhynchus mykiss. Aquaculture, 243: 241-254.

Pooramini, M., K Abolghasem, K., Abdomajid, H., A. Morteza, A., and Rosoul, G.. 2009. Effect of using yeast (Saccharomyces cerevisiae) as probiotic on growth parameters, survival and carcass quality in rainbow trout Oncorhynchus mykis fry. Int. Aquat Res., 1: 39-44.

Rana, K.J., Siriwardena, S., and Hasan, M.R. 2009. Impact of Rising Feed Ingredient Prices on Aquafeeds and Aquaculture Production, Food and Agriculture Organization of the United Nations, Rome, Italy.

Rachmawati, D., Istiyanto, S., and Maizirwan, M. 2017. Effect of Phytase on Growth Performance, Feed Utilization Efficiency and Nutrient Digestibility in Fingerlings of Chanos chanos (Forsskal 1775). 
Philippine Journal of Science, 146 (3): 237-245.

Sakai, M., Taniguchi, K., Mamoto, K., Ogawa, H., and Tabata, M. 2001. Immunostimulant effects of nucleotide isolated from yeast RNA on carp, 433438.

Semih, S., Najdet, G., and Belgin, H. 2009. Replacement of fish meal by yeast (Saccharomyces cerevisiae): effects on Gilthead Sea bream (Sparus aurata). .J Anim. Vet. Adv., 8(12): 2557-61.

Steel, R.G.D., Torrie, J.H., and Dickey, D.A. 1996 Principles and procedures of statistics, 3 rd. ed. New York: McGraw Hill International Book Company, Inc.

Tacon, A.G. J ., Cody . J . J . , Conquest, L.D., Divakaran, S., Forster, I.P., and Decamp, O.E. 2002. Effect of culture system on the nutrition and growth performance of Pacific white shrimp Litopenaeus vannamei (Boone) fed different feeds. Aquaculture Nutrition, 8: 121-137.

Takeuchi, T. 1988. Laboratory Work-Chemical Evaluation of Dietary Nutrient. In: $\mathrm{T}$. Watanabe (ed): Fish Nutrition and Mariculture. Kanagawa Fisheries Training Center, Japan Internasional Cooperation Agency, Tokyo, pp. $179-232$.

Tewary, A. and Patra, B.C., 2011. Oral administration of baker's yeast (Saccharomyces cerevisiae) acts as a growth promoter and immunomodulator in Labeo rohita (Ham.) Aquaculture research advance, 2(1): 1-7.

Tovar, D., Zambonino-Infante, J.L., Cahu, C., Gatesoupe, F.J., Vázquez-Juárez, R., and Lésel, R. 2002. Effect of live yeast incorporation in compound diet on digestive enzyme activity in sea bass larvae. Aquaculture, 204: 113-123.

Wache, Y., Auffray, F., Gatesoupe, F.J., Zambonino, J., Gayet, V., Labbé, L., and Quentel, C. 2006. Cross effects of the strain of dietary Saccharomyces cerevisiae and rearing conditions on the onset of intestinal microbiota and digestive enzymes in rainbow trout, Onchorhynchus mykiss fry. Aquaculture, 258: 470-478.

Welker, T.L. and Lim, C. 2011. Use of probiotics in diets of tilapia. Journal of Aquauclture Research and Development S1 : 014 . doi : 10 . 4172 / 2155 - 9546. S1-014. 